\title{
The telecom value chain, opportunities and revenues created by the nigerian telecom boom
}

\author{
Nsikan Nkordeh ${ }^{1}$, Uzairue Stanley Idiake ${ }^{2}$, Ibinabo Bob-Manuel ${ }^{3}$, Francis Anyasi ${ }^{4}$ \\ ${ }^{1,2}$ Department of Electrical and Information Engineering, Covenant University, Nigeria \\ ${ }^{3}$ IT Consultant, Nigeria \\ ${ }^{4}$ Department of Electrical and Electronics Engineering, Ambrose Alli University, Nigeria
}

\begin{tabular}{l} 
Article Info \\
\hline Article history: \\
Received Mar 11, 2018 \\
Revised Jul 12, 2018 \\
Accepted Aug 1, 2018 \\
\hline
\end{tabular}

\section{Keywords:}

Opportunities

Revenue

Telecoms

Value chain

\begin{abstract}
In Nigeria today, we face a serious economic challenge which is as a result of our swindling primary source of revenue (oil), there is fear amongst our economists which is can Nigeria bounce back to what she once was? Can there be an alternative source to serve as a buffer to what we already have. This study aims to bring to prime focus, an industry which has begun blooming in the background. Despite the publicity and popularity enjoyed by today's telecom giants in the country, there is very little knowledge pertaining to the tremendous impact that it has had directly or indirectly on our economy over the years. Since the liberalization of the telecom industry that brought about the involvement of private investors into the sector, the opportunities and revenues generated has brought about a tremendous effect on the economy. The telecom sector is only second after the oil and gas industry in the amount of finance it contributes to the federal account. This paper discusses some of the value chains, opportunities, revenue that the telecom industry has brought to Nigeria. It uses data obtained from relevant authorities.
\end{abstract}

Copyright (C) 2019 Institute of Advanced Engineering and Science. All rights reserved.

\author{
Corresponding Author: \\ Uzairue Stanley, \\ Department of Electrical and Information Engineering, \\ Covenant University, \\ Ota, Ogun State, Nigeria. \\ Email: Stanley.uzairue@covenantuniversity.edu.ng
}

\section{INTRODUCTION}

The Nigerian economy has been on a major down turn since the crash in the price of crude oil, resulting in a serious degeneration in the dwindling revenue generated from the formerly largest source unlike as it was in previous years. That has led to the conscious realization that another alternative should be sought. Nigerian experts are of the opinion that the Telecommunication sector in the country is a possible major solution to the nation's economic woes [1]. From the onset, as Nigeria became a growing market, it was utterly disregarded as a spring of significant income due to cecity its potential by alternative sources. In 1992, the Nigerian Government came to the decision to begin deregulation of the telecommunication industry to bring together world investors to boost this private sector. Every private sector in growing economies thrives solely by foreign investors. The Nigerian Communications Commission (NCC) was created in same year to serve as the required regulating body for telecommunications services. This was the first step to initiating what is seen today to be one of the fastest growing sectors of the Nigerians economy. This development has been stimulated by variety factors which include the deregulation policy of the Nigerian government, worldwide increased development of telecommunications and information technology and the potential of the market. The telecommunication industry underwent some structural changes and large scale growth leading to the telecom revolution. In the year 2001 the advent of mobile telecommunication had just begun. The number of users since the telecom boom has steadily increased by the thousands. 
Figure 1 shows a study by NCC showing the rise in teledensity since the onset of the telecom boom. Since then the opportunities created have been undeniable even to the common man. According to Soyinka Adebayo [1] said "the mobile phone has given power to the poor by opening up real window of wealth creation for them to get out of the scourge of poverty".

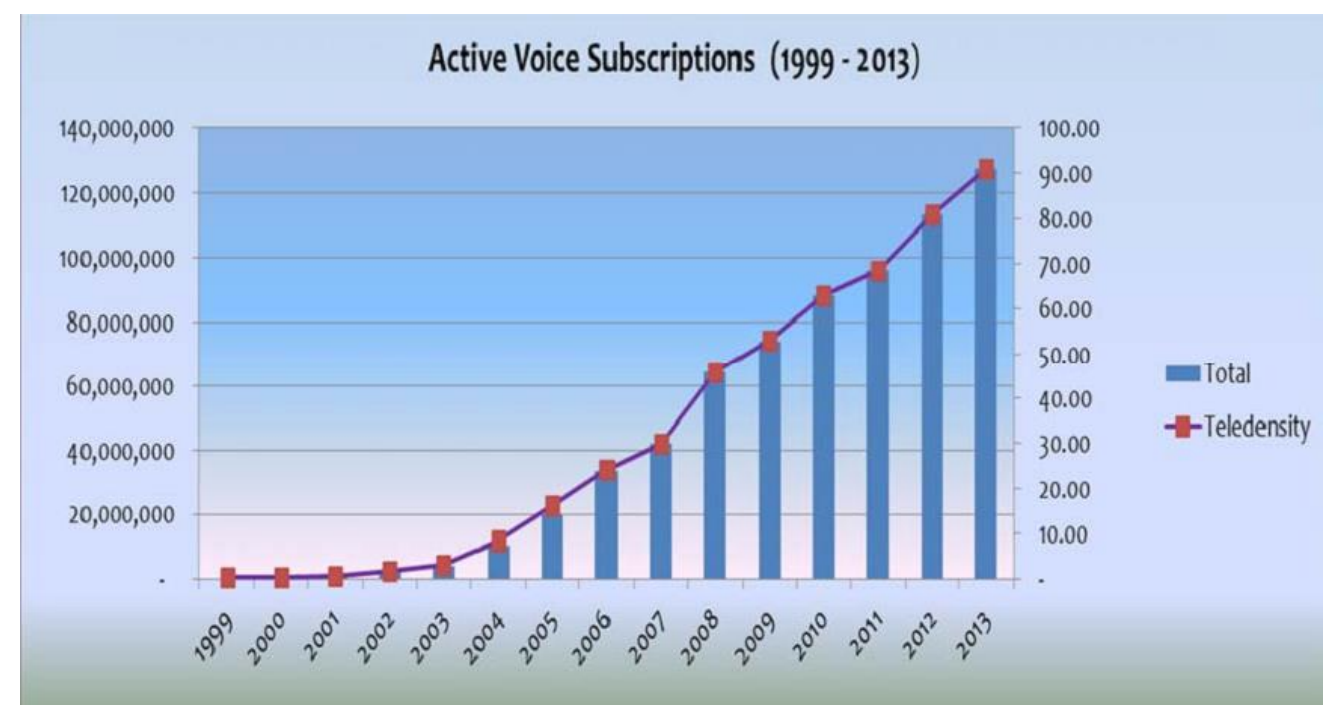

Figure 1. Active voice subscription from 1999-2013 [2]

In the past decade, the Telecommunication industry has made a tremendous impact on the Nigerian economy generating billions year after year. This study simply brings to light how telecommunications can foster economic development in Nigeria.

\section{LITERATURE}

Before the advent of mobiles, Nigeria had a congested, expensive and un-user friendly landline system with more than 10 million people waiting to be connected by the state-run telecoms [2].

The telecommunication industry contributes N1.41 billion to Nigeria's GDP in 1st quarter of 2016 [2]. The last decade, the Nigerian Telecommunication industry has experienced development leading to a rapid increase in the nations GDP. Telecomcompanies such as MTN, Airtel, Glo, Etisalat, $21^{\text {st }}$ Century has contributed immensely to Nigeria's economy by creating revenues and job opportunities. The telecommunications sector contributed N 1,580 billion to GDP in the second quarter of 2016, or 9.8\% [2].

\section{OPPORTUNITIES IN THE TELECOM INDUSTRY}

In the years gone by we have seen the number of subscribers' increase. Due to this increase the need for recharge cards by the consumers has increased and this has brought about the increase in the number of retailers of recharge cards across Nigeria. It also important to note that the telecommunication industry has provided about 10 million jobs for the past 10 years [3]. It is also the second most contributing industry to the nations GDP [3].

The deregulation of the telecommunication sector in 1922 through degree 75 allow private sector participation in the sector and expand the nations' communication facilities [4]. This brought about the Local Manufacturing of Equipment: There was an urgent need to expand the infrastructural facility relating to the telecoms industry. This will effectively improve the economic, social, political, cultural development in the country. This cannot be achieved if the equipment is imported. Therefore, it is a better for the equipment and spares to be locally manufactured. In this way, indigenous investors could be able to invest their resources into the local manufacture. The result of the telecom boom has brought about lucrative business ideas. 


\section{BUSINESS OPPORTUNITIES}

The result of the telecom boom has brought about lucrative business ideas. This business ideas when exacted has made the Nations' economy and also unemployment rate to be reduced. The business ideas can be broadly divided into;

\subsection{Cables}

In Nigeria, there are three companies involved in the production of telecommunication cables using imported copper and other local resources like PVC (Poly vinyl chloride) used for insulation. Also the telecom boom in Nigeria has brought about the increase in the acquirement of fibre optics. Table 1 present fibre optics in KM (in 2014). Fibre optics covered 3,774km in 2006 and in 2012 it covers over 22,982km [6]. Therefore, the telecom industry has created the market for the sale of fibre optics because as at December 2014 the telecoms operating companies had deployed a combined total of 80,938km of fibre optics [5]-[7]. Figure 2 present graph of onland activities against submarine activities.

\begin{tabular}{lcc}
\multicolumn{3}{c}{ Table 1. Fibre optics in KM (in 2014) [6] } \\
\hline & Onland & Submarine \\
\hline MTN & 19,200 & - \\
GLO & 10,869 & 9,800 \\
AIRTEL & 6,314 & 23 \\
EMTS & 4,300 & - \\
MULTILINKS & 5,789 & - \\
VISAFONE & 43 & - \\
MTN-FXD & 12,518 & 6,682 \\
$2^{15}$ CENTURY & 5000 & 1 \\
ipNX & 400 & 424 \\
TOTAL & 64,433 & 16,506 \\
\hline & &
\end{tabular}

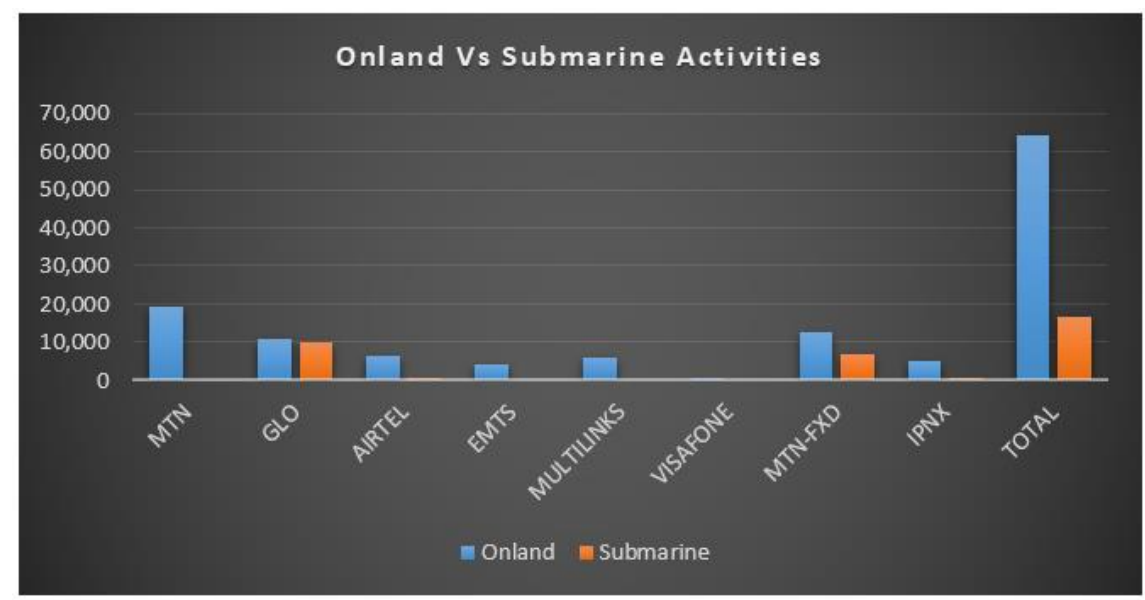

Figure 2. Graph of onland activities against submarine activities

\subsection{Facilites and services}

The population of Nigeria is over 140 million people, there has been an increase in the telephone capacity from 500,000 in 2001 to over 35M in 2007 [7]. This has brought about an increase in the facilities and services provided by the telecommunications industry. Also in the telecom industry there has been an expansion in the number of base stations nationwide. The desired expansion may not be achieved under the present prevailing circumstances where the needed equipment is usually imported with attendant problems of foreign exchange procurement, freighting cost, long delivery period, etc. There is therefore no other realistic option than to encourage and involve in the local production of these equipment and spares. Local manufacturing of switching and transmission equipment is required since no single company exists in Nigeria or even neighbouring countries for this purpose. Hence, any company that goes into the venture will have its market beyond Nigeria's economic frontiers. [2s] Also, services such as Internet services, Payphone services Cellular radio phone services has also been provided as a business opportunity for individuals [8]-[10]. Data presented in Table 2 and graphs presented in Figure 3. 
Table 2. Statistics Showing the Amount of Base Stations [8]

\begin{tabular}{cccccc}
\hline YEARS & MTN & GLO & AIRTEL & EMTS & VISAFONE \\
\hline 2013 BASE STATIONS & 11,551 & 6,305 & 5,997 & 4,436 & 567 \\
2014 BASE STATIONS & 12,557 & 6,677 & 6,186 & 4,756 & 695 \\
\hline
\end{tabular}

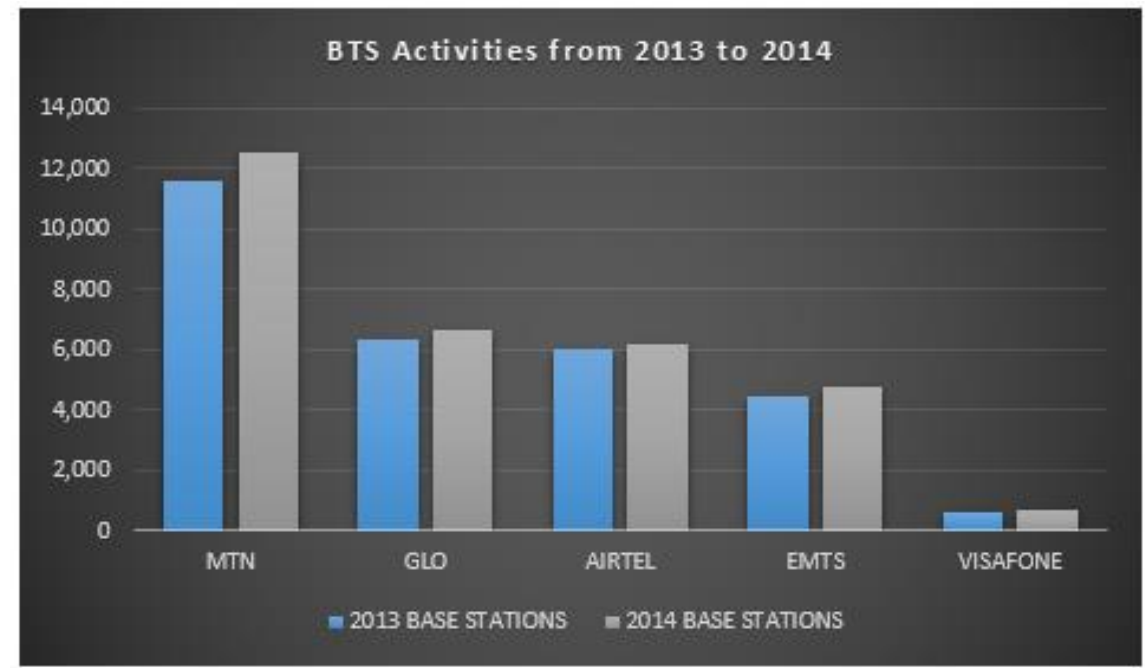

Figure 3. Base station activities from 2013 to 2014

\subsection{Employment oppurtunities}

Also the telecommunication sector has produced quite a number of jobs for the Nigerian people. In the year 2011 a total number of 8,319 people were employed of which $96.7 \%$ of them are Nigerians while the expatriate accounted for the remaining 3.3\% [8]-[10]. Of this $96.7 \%$ that are Nigerians $68.14 \%$ are males. Females accounted for the remaining $31.86 \%$. Although in the year 2012 there was a $39.4 \%$ decrease in the number of employees in the telecom sector. The number of Nigerian males and females reduced by $48.4 \%$ and $14.6 \%$ respectively. In the year 2013 the number of employees in the telecom sector increased by a tremendous $79.1 \%$. The number of Nigerian males increased by a $107.7 \%$ and the number of Nigerian females increased by $33.1 \%$ from the previous year [8]-[10]. Data presented in Table 3 and graphs presented in Figure 4.

Table 3. Data Showing the Total Number of Employees from 2011 to 2013 [11]

\begin{tabular}{ccccc}
\hline 2011 & Sex & Nigerian & Expatriate & Total \\
& Male & 5,482 & 268 & 5,750 \\
& Female & 2,563 & 6 & 2,569 \\
& Total & 8,045 & 274 & 8,319 \\
\hline 2012 & Sex & Nigerian & Expatriate & Total \\
& Male & 2,826 & 28 & 2,854 \\
& Female & 2,188 & 0 & 2,188 \\
& Total & 5,014 & 28 & 5,042 \\
\hline 2013 & Sex & Nigerian & Expatriate & Total \\
& Male & 5,871 & 241 & 6,112 \\
& Female & 2,912 & 7 & 2,919 \\
& Total & 8,783 & 248 & 9,031 \\
\hline
\end{tabular}



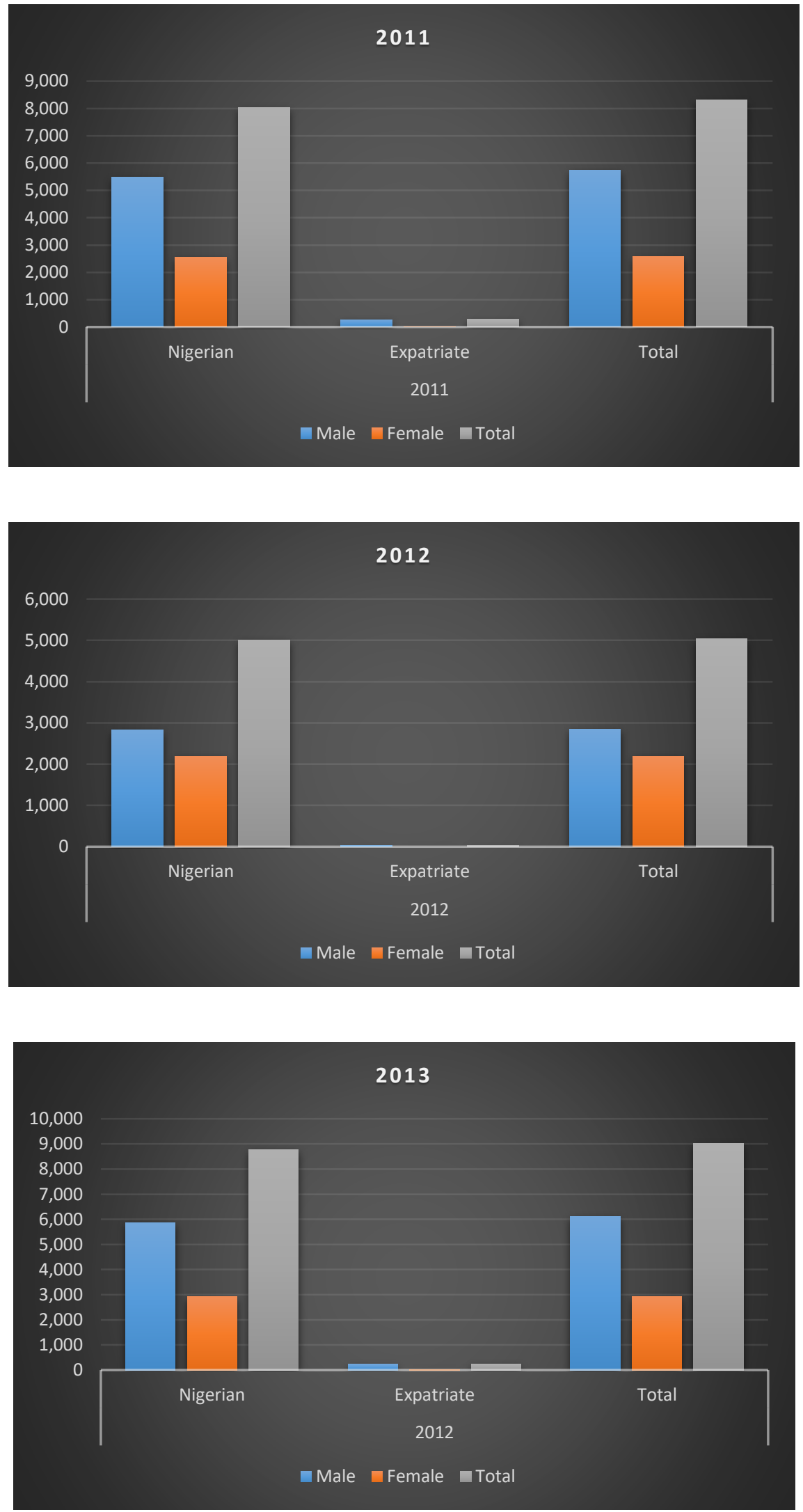

Figure 4. Graphs showing the total number of employees from 2011 to 2013 


\section{REVENUE GENERATED FROM THE TELCOMMUNICATION INDUSRY}

Nigeria is considered as the largest telecommunication market in Africa. [11] The nations' economy is undergoing a speedy transformation on account of explosive growth and rapid development in the infrastructure. First of all, revenue is the income of a government from all sources, used to pay for a nations' expense. In the year 2012 the telecom sector generated a revenue of U. S\$9.3 billion. [12] In the year 2013 a total of U. S\$9.2 billion. MTN, Airtel, Glo, Etisalat and Visafone dominatesthe Nigerian telecom market and, telecoms growth in the country is dominated by the mobile sector. With revenue of $\$ 7.1$ billion, the mobile voice segment was the largest contributor towards overall telecoms revenue in 2013. In the year 2014 the telecom sector generated a revenue to the tune of U.S\$9.8 billion. This is a 6.8 percent increase over 2013. As with the trend the mobile voice segment contributed the most at U. S\$7.3 billion. This is about 200 million increase from that of last year. [13] In the last quarter of 2015 the telecom industry generated a revenue of N1, 645 billion. In the first quarter of 2016 the telecommunication industry contributed N1.41 billion to Nigeria's GDP. This means that the revenue generated by the telecom industry in the first quarter of 2016 is N1.41 billion. [14-15] In the second quarter of 2016 the telecom industry generated a revenue of N1, 580 billion 167].

\section{DISCUSSION}

From data presented in Table 3 and graphs presented in Figure 4, it can be shown that this growth in telecommunication sector was largely contributed by Nigerian of which male counterpart took the highest percentage as against the female counterpart. In year 2012 it was observed that there was a lower percentage of expatriate in the sector and the impact in the GDP was positively affected. Figure 5 present impact of telecommunication growth on sectoral real GDP from 2011 to 2012. Therefore, it would be wrong if we conclude by saying the telecommunication industries are largely being managed by Nigerians telecommunication expert. And it could also be noticed that in the next five years, there might not be expatriate in Nigeria telecommunication industries as indigenous expert will fully take control of the market.

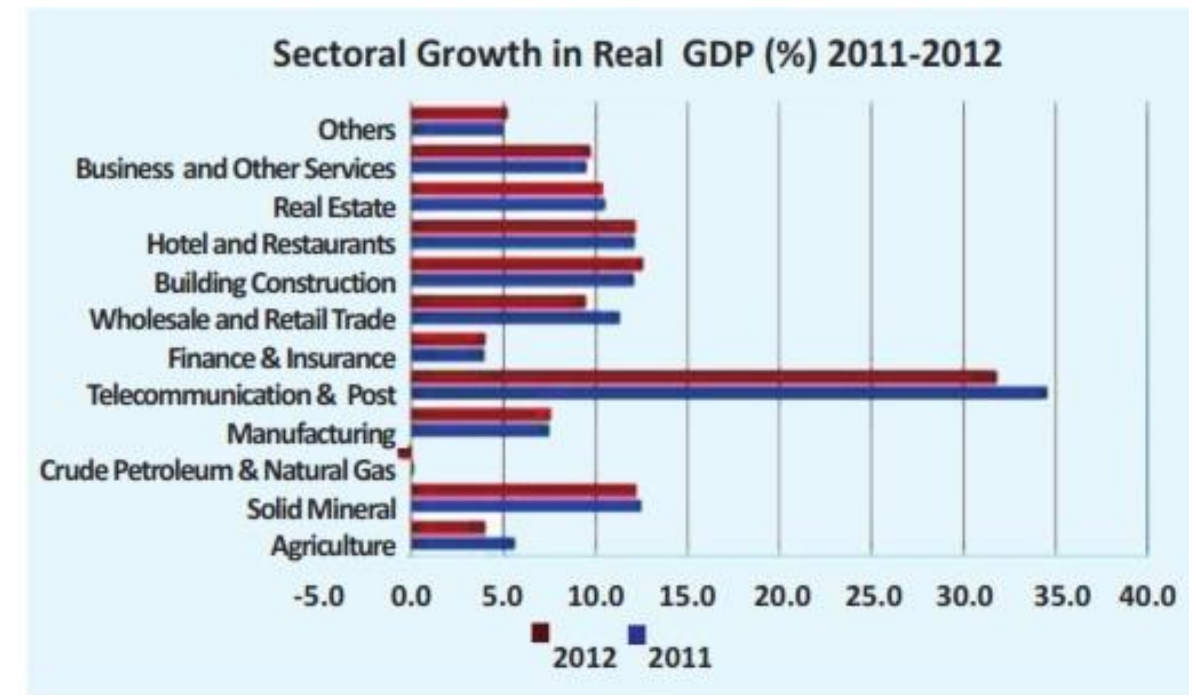

Figure 5. Impact of Telecommunication Growth on Sectoral Real GDP from 2011 to 2012 [16]

\section{CONCLUSION}

The fortunes of Nigeria's telecommunication market are set to increase as the sector is expected to generate a revenue of $\$ 10.9$ billion in 2019 , up from a total of $\$ 9.2$ billion in 2013 [8]. From this data it is obvious that the revenue expected to be generated by the telecommunications industry is expected to increase by $18.4 \%$ over the next six years from 2013, Also the telecommunications industry in Nigeria contributes 10 percent of the nation's Gross Domestic Product (GDP), which makes it second only to the oil and gas industry. The revenue accrued from the telecom sector is second behind that from the oil and gas industry. In the last 10 years the telecom industry has contributed over 500 billion to the federation account. This figure is that gotten from the taxes been paid by the telecom companies. The telecom industry has also created about 2.5 million jobs either directly or indirectly still over the last 10 years. The telecom industry has also attracted over U. S\$40 billion of direct foreign investment into the country since 2013. [16] From the above figures it can be 
seen that the revenue from the telecom industry will only continue to rise either in form of taxes or other forms. The telecom industry is also attracting foreign investment in Nigeria which is of a great help to the Nigerian economy. In the graph below it would also be seen that the telecommunication sector had the highest growth in the real GDP. (GDP which is gross domestic product is the country's income minus foreign investments).

\section{REFERENCES}

[1] Adebayo Folashade, (2008). "Seven years of telecoms - the fun and the fury". TellMagazine of Nigeria, 7: 50-55.

[2] Agoi .J. Olatunde (August 25, 2008) Mobile Telecom Boom Work Changes in Nigeria:http://www.chinapost.com (Thursday October 6, 2016).

[3] Lucas Ajanaku (June 07, 2016) "Fixing Nigeria's ailing economy with ICT" The Nation Newspaper.

[4] Soyinka Adejuwon, (2008). "Seven years of telecoms revolution - Breeding jobs for the masses". Tell Magazine of Nigeria, 7: 30-32.

[5] National Bureau of Statistics (2016) Nigerian Telecommunications (Services) Sector Report Q2: http://www.nigeriastat.gov,ng (2015).

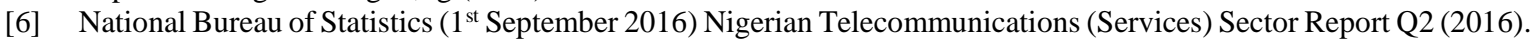

[7] Nigerian Communication Commission (2016) Telecommunications Report Full 2016 Quarter 2: http://www.ncc.org.ng

[8] Nigerian Communication Commission (2014) Year End Subscriber/Network Data Report for Telecommunicating Operating Companies in Nigeria: http://www.ncc.org.ng

[9] Nigeria Galleria (2015) Investment Opportunities in Telecommunications Industry: http://www.nigeriagalleria.com

[10] The Herald ( $8^{\text {th }}$ October 2016) "Nigeria's Got N500b, 2.5m Jobs from Telecoms Industry in 10 Years-NCC" (March 18 2016) by Dami: http://www.theherald.com

[11] The News (Thursday $6^{\text {th }}$ October, 2016) "Tele Sector Contributes N1.4bn to Nigeria's GDP in $1^{\text {st }}$ Quarter of 2016NBS": http://www.thenewsnigeria.coms

[12] Summary report on telecommunication for national and international regions: 2010-2014. http://www.nigeriastat.gov.ng

[13] The Guardian Newspaper 2014 "Nigeria's telecoms industry generates $\$ 9.3 \mathrm{~b}$ in 2012".

[14] Design and Analysis of a Broadcast Network Using Logical Segmentation A Francis, U Stanley, ON Enehizena, VM Olu, A Peter, N Nkordeh TELKOMNIKA (Telecommunication Computing Electronics and Control) 16 (2) 2018.

[15] Uzairue Stanley etal: Experimental Analysis of Cable Distance Effect on Signal Attenuation in Single and Multimode Fiber Optics, International Journal of Electrical and Computer Engineering, Vol 8, No 3 June 2018.

[16] Anyasi, F.I and Uzairue, S.I: Determination of GSM Signal Strength in Some Selected Location in EKPOMA: IOSR Journal of Electronics and Communication Engineering (IOSR-JECE); Volume 9, Issue 2, Ver 2 (Mar-Apr. 2014), PP 08-15. 